\title{
Study on Climatic Variation and Its Effect on Vegetable Type Soybean Genotypes at Khumaltar, Lalitpur in the Last Ten Years
}

\author{
Santosh Raj Tripathi ${ }^{1 *}$, Jiban Shrestha ${ }^{2}$, Jagat Devi Ranjit ${ }^{3}$, Reshma Neupane ${ }^{4}$ \\ ${ }^{1}$ RARS, Khajura, ${ }^{2}$ NMRP, Rampur, ${ }^{3,4}$ Agronomy Division, Khumaltar, Nepal Agricultural Research Council (NARC), Nepal
}

\section{A R T I C LE IN F O}

Article history:

Received 18 December 2014

Accepted 02 April 2015

Available online, ISSN: 2148-127X

Keywords:

Climate variation

Glycine max

Seed yield

Ten years

Khumaltar

* Corresponding Author:

E-mail: santoshrajtripathi@gmail.com

\section{A B S T R A C T}

Soybean (Glycine max L. Merril) is widely grown in the mid hills as intercrop with maize or in paddy bunds, while it is gaining popularity as sole crop in terai and inner terai. Mean temperature at Khumaltar during soybean growing period was mostly fluctuating; but we observed an increasing trend in temperature. Amount of rainfall was not changed dramatically but number of rainy days was decreased during study period. Rainfall during germination time increase soil moisture which also increase germination and found higher early stand. Days from sowing to $50 \%$ flowering and $90 \%$ maturity were short in the case of higher minimum temperature and low rainfall. Among the genotypes, AGS377, AGS-378, AGS-379 and Tarkari Bhattmas-1 were more sensitive. However, seed yield decreased in the case of higher temperatures and low rainfall. Cool night temperatures and high moisture increased disease incidence in soybean which, eventually reduced yield. In last three years, plant suffered from moisture stress during early vegetative stage and high moisture during late vegetative stage which reduced seed yield and seed weight. In conclusion, we found that genotypes like AGS- 360, Sathiya and Tarkari Bhatmas-1 are very sensitive to climatic variation.

\section{Introduction}

Soybean (Glycine max L. Merril) is widely grown in the mid hills as intercrop with maize or in paddy bunds, while it is gaining popularity as sole crop in terai and inner terai. In mid hills and valleys soybean production occupies about $80 \%$ of the total agricultural area. It occupies an area of 24934 ha with the total production of $29221 \mathrm{mt}$ and the average productivity of $1172 \mathrm{~kg} / \mathrm{ha}$ in 2012/13 (MOAD, 2014). Soybean has a diverse adaptability to varied agro-ecological zones with an altitude ranging from 200 to $2000 \mathrm{~m}$ above mean sea level (Sharma, 1994). Soybean seed contains high amount of protein (45-50\%), oil (20\%), and rich in vitamin B, C, E and minerals (NGLRP, 2011). It can be used as a good supplemental food especially in the underdeveloped countries where majority of population suffers from malnutrition. Soybean has a very diverse utilization such as seeds can be used to prepare baby food and food for diabetic patients, green pods can be used as green vegetables and dry seeds can be eaten roasted or fried. Soybean cake and meal are utilized for preparing various livestock and poultry feeds. Demand for soybean is in current increase with increase in poultry business and majority of soybean meal is imported from India (Shrama, 2012).

Nepal today has faced with great challenges to produce adequate amount of soybean. Climatic changes associated with increasing atmospheric concentration of carbon dioxide $\left(\mathrm{CO}_{2}\right)$ and other "greenhouse gases" most importantly global warming and increasing ozone $\left(\mathrm{O}_{3}\right)$ concentrations in the lower atmosphere across large cropgrowing region (Bartlett et al. 2010). Observational evidence indicates that recent regional changes in climate, particularly temperature increases, have already affected a diverse set of physical and biological system in many parts of the world (Beggs, 2004).

Soybean grows well in warm and moist climate. Soil temperatures of $15.5^{\circ} \mathrm{C}$ or above favor rapid germination and vigorous seedling growth (Krishna and Sachdev, 2014). The minimum temperature for effective growth is about $10^{\circ} \mathrm{C}$ and lower temperature tends to delay the flowering. Day length is the key factor in most of the soybean varieties as they are short day plant and are sensitive to photo-periods. Most of the varieties will flower and mature quickly if grown under condition where the day length is less than 14 hours provided that temperatures are also favorable (Krishna and Sachdev, 2014). Inadequate soil moisture during germination causes uneven and spotty emergence. Stress at vegetative stages reduces shoot growth, but not root growth. These conditions diminish water use by the plants and increase their ability to extract water from the soil. Very high soil temperatures (32degrees Celsius) can cause decreased nodulation and nitrogen fixation to occur in soybeans (Rahmani et al., 2009). Flower production can occur for 30 to 40 days under optimum growth conditions. Moisture stress and high temperatures shorten the flowering period 
(Jonathan et al., 2004).

During the pod development stage, drought-stressed soybean plants will abort both flowers and pods. Temperatures above 35 degrees Celsius have been shown to significantly decrease pod set (Staton, 2012). Leaf loss can also occur in severely stressed plants. If the moisture stress ends, soybeans will produce new flowers and pods up to the seed formation stage. Soybean yield losses will be the greatest due to reduces the number of pods per plant when stress occurs at seed development stage (Zheng et al., 2002).

The general objective of this study is to highlight the climatic variation in a 10 year period and its effect on vegetable type soybean genotypes at Khumaltar, Lalitpur.

\section{Materials and Methods}

Twelve soybean AVRDC genotypes including check variety Tarkari Bhatmas-1 and Sathiya were conducted in Khumaltar evaluated for morphological and agronomical traits. Data from 2001 to 2011 was reviewed and correlated with environmental data.

\section{Results and Discussion}

Maximum, minimum temperature, rainfall and rainy days were recorded in Khumaltar meteorological station during these studies.

\section{Study of Climatic Parameters}

Maximum temperature: Mean temperature at Khumaltar during soybean growing period was mostly fluctuating; but we observed an increasing trend in temperature (Figure 1). This increased maximum temperature decreased crop growth period and increased moisture stress. High soil temperatures $\left(90^{\circ}\right.$ degrees Fahrenheit) can cause decreased nodulation and nitrogen fixation to occur in soybeans (Thuzar et al., 2010). Temperature increases lead to higher respiration rates, shorter periods of seed formation and, consequently, lower biomass production. For example, higher temperatures result in a shorter grain filling period, smaller and lighter grains and, therefore, lower crop yields and perhaps lower grain quality (i.e. lower protein levels).

Minimum temperature: Minimum temperature or night temperature is very important for crop production. In high night temperature respiration increase which decrease food supply to soybean pod. In other hand, very low temperature $<15^{\circ} \mathrm{C}$ also increased flower drop and sterility during reproductive stages. The minimum temperature at Khumaltar had decreasing trend (Figure 2) at reproductive period and increasing in vegetative growth period.

Total rainfall: The rainfall fluctuations in Khumaltar have been largely random over a study period, with no systematic change detectable in summer monsoon season (Figure 3). In last five year, maximum rainfall occurs in August which consider with soybean flowering time. Rainfall during flowering stage caused soybean malformation and flower drop. Soybeans can tolerate moisture stress relatively well during the vegetative stages. Stress at this time reduces shoot growth, but not root growth. These conditions diminish water use by the plants and increase their ability to extract water from the soil.

Total rainy day: Total rainy days in Khumaltar was fluctuating but decreasing trend (Figure 4). Amount of rainfall was not so decreased but rainy day was decreased. This showed that rainfall was not well distributed. Sometime crop suffer from moisture stress and sometime suffer from water lodging problem.

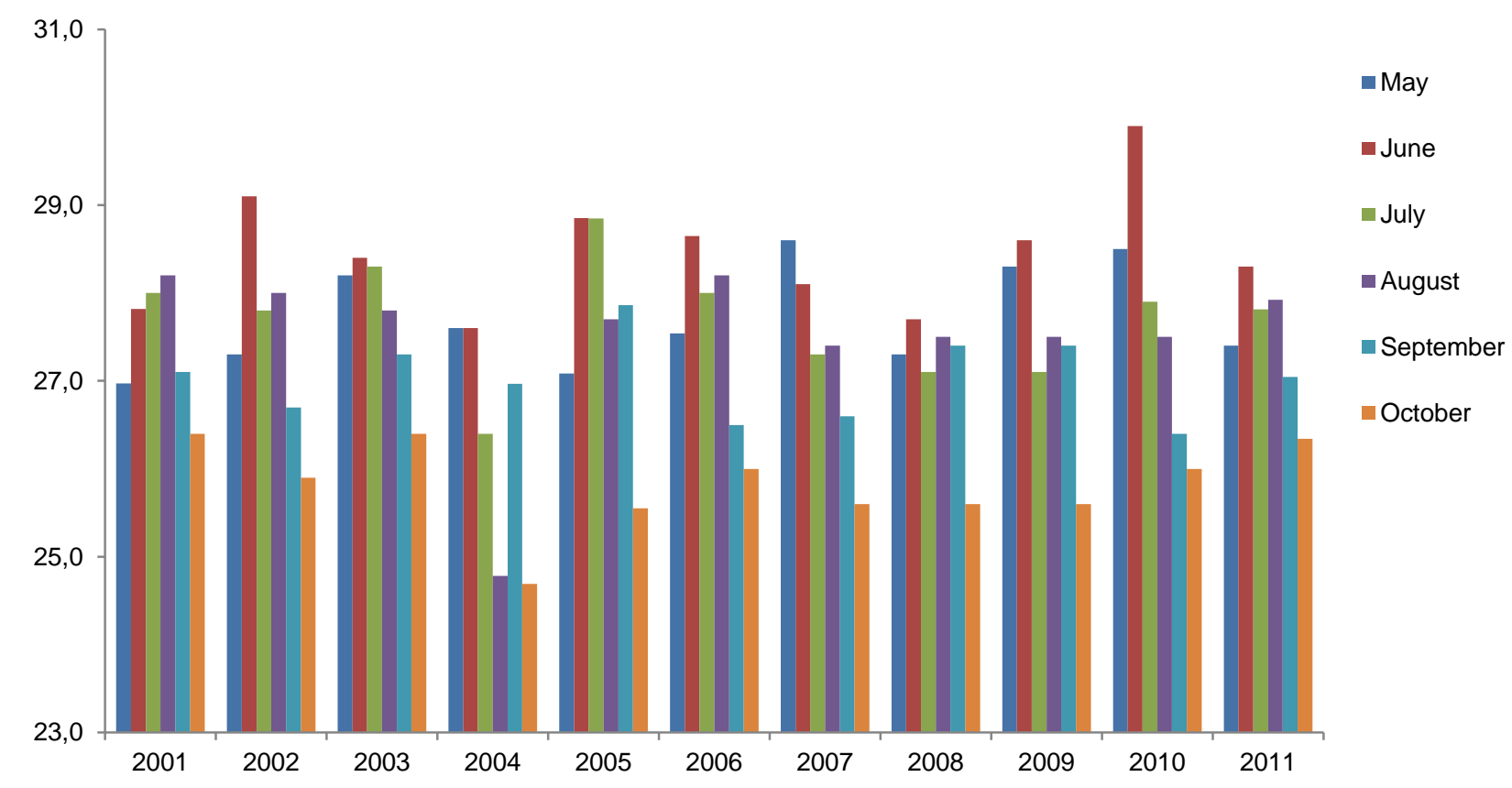

Figure 1 Monthly mean maximum temperature at Khumaltar from 2001 to 2011 


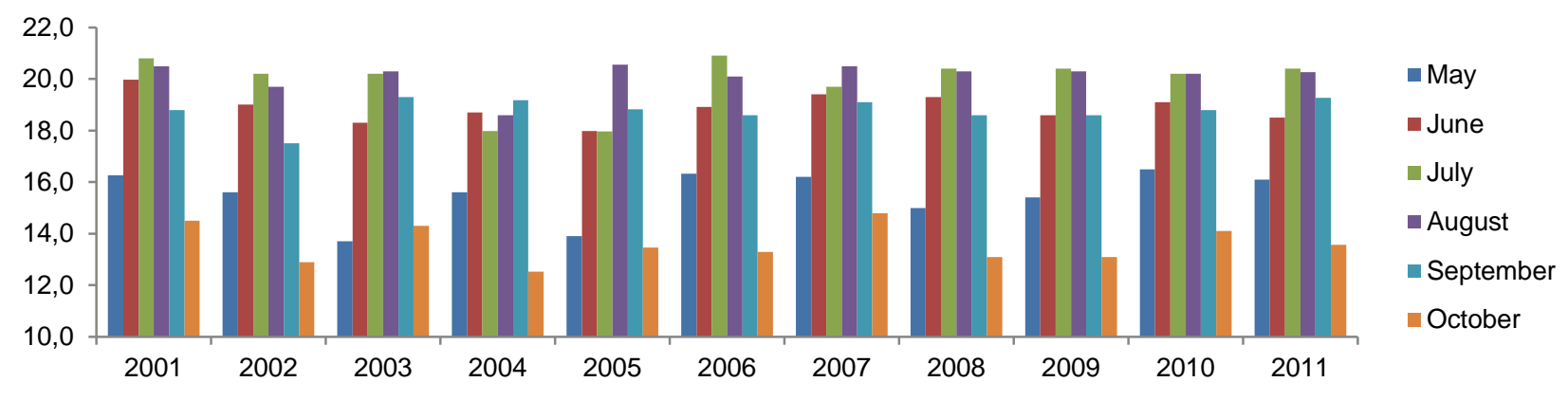

Figure 2 Monthly Mean Minimum Temperature at Khumaltar from 2001 to 2011.

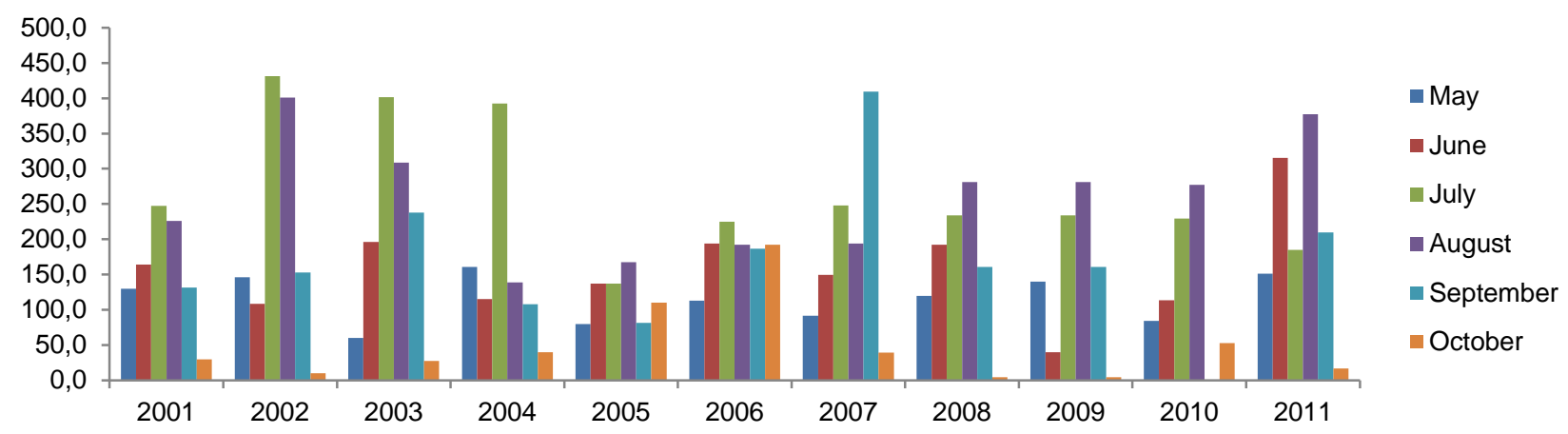

Figure 3 Monthly Total Rainfall at Khumaltar from 2001 to 2011.

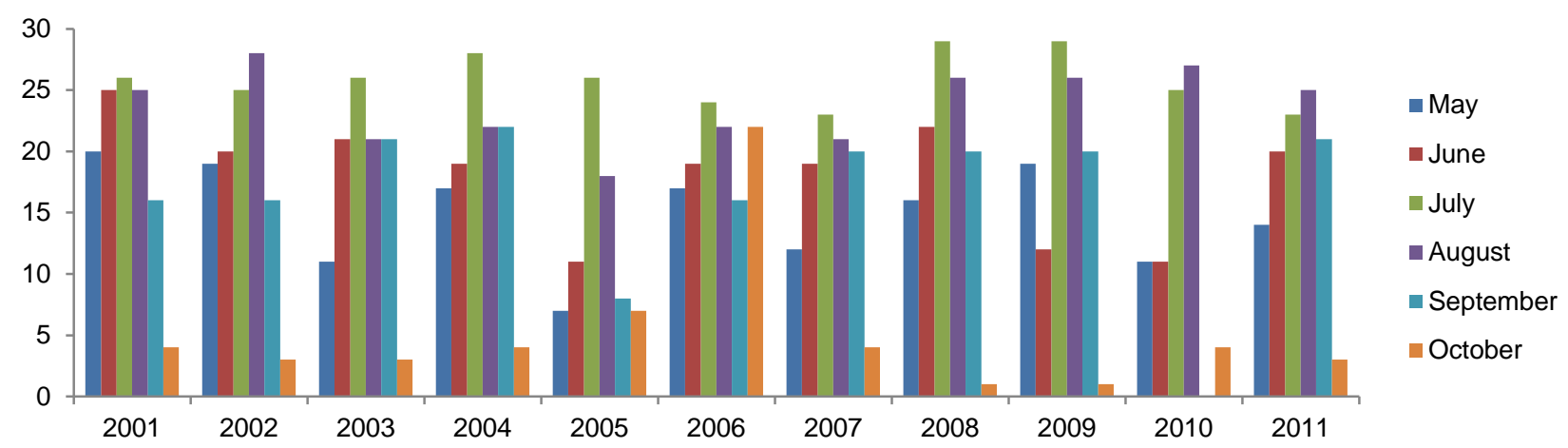

Figure 4 Monthly Total Rainfall at Khumaltar from 2001 to 2011.

\section{Effect on Crop}

More subtle fluctuation in weather during critical phases of crop development can also have substantial impact on yields.

Early plant stand: Soybean required optimum temperature and soil moisture for good germination. Soybean required 15.5 to $30^{\circ} \mathrm{C}$ and soil moisture more than $70 \%$ of field capacity. Soybean germination was affected by rainfall during germination stage. Rainfall in second week of May and first week of June i.e. sowing time increase early plant stand high (Figure 5). Data presented in appendixes 1 .

Days to $50 \%$ flowering: Soybean required $20-25^{\circ} \mathrm{C}$ for flowering. Days from sowing to $50 \%$ flowering was depended on moisture and temperature. Moisture stress and high temperatures shorten the flowering period. In last five year, days from sowing to $50 \%$ Flowering was decreased (Figure 6) and data presented in appendix 2. Physiologically, the high temperatures during reproductive development may cause flower abortion, sequent sink site, and later pod abscission resulting decreased number of seeds per plant (Duthion and Pigeaire, 1991). Pollen development, fertilization, and asynchrony of stamen and gynoecium's development are sensitive to temperatures during flowering (Boote et al., 2005).

Days to $50 \%$ maturity: A temperature of $15-22^{\circ} \mathrm{C}$ is optimum for maturity (Thuzar et al., 2010). High temperature hastens crop development and therefore shortens the seed filling duration. In figure 7, days from sowing to $90 \%$ maturity was short where rainfall was low and hot night during pod development. Among the genotypes, AGS-377, AGS-378, AGS-379 and Tarkari Bhattmas-1 were more sensitive than others. Prasad et al. (2000) also reported short maturity days where air temperature was $38^{\circ} \mathrm{C}$ during flowering to maturity and $50 \%$ reduction in pod yield.

Seed yield: Soybean seed yield is greatly affected by 
temperature during early vegetative growth period and seed formation and development stage. The suitable temperature for soybean is $15-22^{\circ} \mathrm{C}$ at emergence, 20 $25^{\circ} \mathrm{C}$ at flowering, and $15-22^{\circ} \mathrm{C}$ at maturity (Liu et al., 2008). Soybean seed yield components are also influenced by temperature. Soybean seed yield increased as temperature increased from 18/12 (day/night) to $26 / 20^{\circ} \mathrm{C}$, but decreased when plants were grown at temperatures greater than $26 / 20^{\circ} \mathrm{C}$ (Thuzar et al., 2010). Yield in soybean is highly affected by drought stress, particularly when the stress occurring during flowering and early pod expansion (Dornbos and Mullen, 1991). Yield loss is due mainly to an increased rate of pod abortion resulting in a less number of seeds per unit area. Stress significantly decreased pod set up to $40 \%$ and the critical stage for pod abortion was 3-5 days after anthesis, when cell division was active in the ovaries (Thuzar et al., 2010). Drought at later stages when pod filling had begun reduced seed size but had no significant effect on pod set. Likewise, rainfall during flowering stage, flowering bud convert into vegetative bud as well as flower and pod drop, then seed yield decrease (Nafziger, 2012). In 2004 and 2007, more rainfall occurred during flowering stage and seed development stage and mean temperature was below $24^{\circ} \mathrm{C}$ during pod filling stage i.e. July to September, so seed yield was drastically reduced. Stress at this time reduced the number of pods per plant as the plants were no longer able to produce new blossoms and pods. This is the major source of the lost yield. In cool night temperature and high moisture increase disease incidence in soybean which also reduce seed yield. In the 2010 and 2011, plant suffers from moisture stress during early vegetative stage and high moisture during late vegetative stage which reduced seed yield. Genotypes like AGS- 360, Sathiya and Tarkari Bhatmas-1 are very sensitive to climatic variation (Figure 8). Soybean seed yield at Khumaltar is presented in appendix 4.

Temperature increase in October increased seed yield (Table 1). This increase in seed yield was due to decreased seed damage during ripening by frost and increase seed weight. The frost reduce pod per plant and reduced seed size all contributed to overall yield loss (Berglund, 2012). However, increased temperatures in May decreased seed yield. In high temperature in germination stage decrease early stand which ultimately decrease seed yield in vegetable soybean (Thuzar et al., 2010). Among the genotypes, AGS-352, AGS-361, AGS378 and AGS-380 are more temperature responsibly than other genotypes. Similarly, heavy rainfall during July i.e. vegetative growth stage and September i.e. pod filling stage showed lower seed yield. This was due to high moisture favor foliar disease development and also effect on root respiration which ultimately decrease seed yield in soybean (Mills and Dorrance, 2009).

Test weight (Thousand grain weight): The factors affecting seed yield also affect the seed weight. Low temperature during pod filling stage, photosynthesis decrease which ultimately decrease seed weight (Thuzar, 2010). Likewise, low and very high moisture at first ten days of seed filling stage also reduce seed weight (Staton, 2012). Seed weight per plant decreased when day temperatures were $35^{\circ} \mathrm{C}$. In the last five years, total rainfall and rainy days in September-October decreased, so soybean seed weight was decreased (Table 6). Similarly, seed luster also reduced due to low temperature at maturity stage.
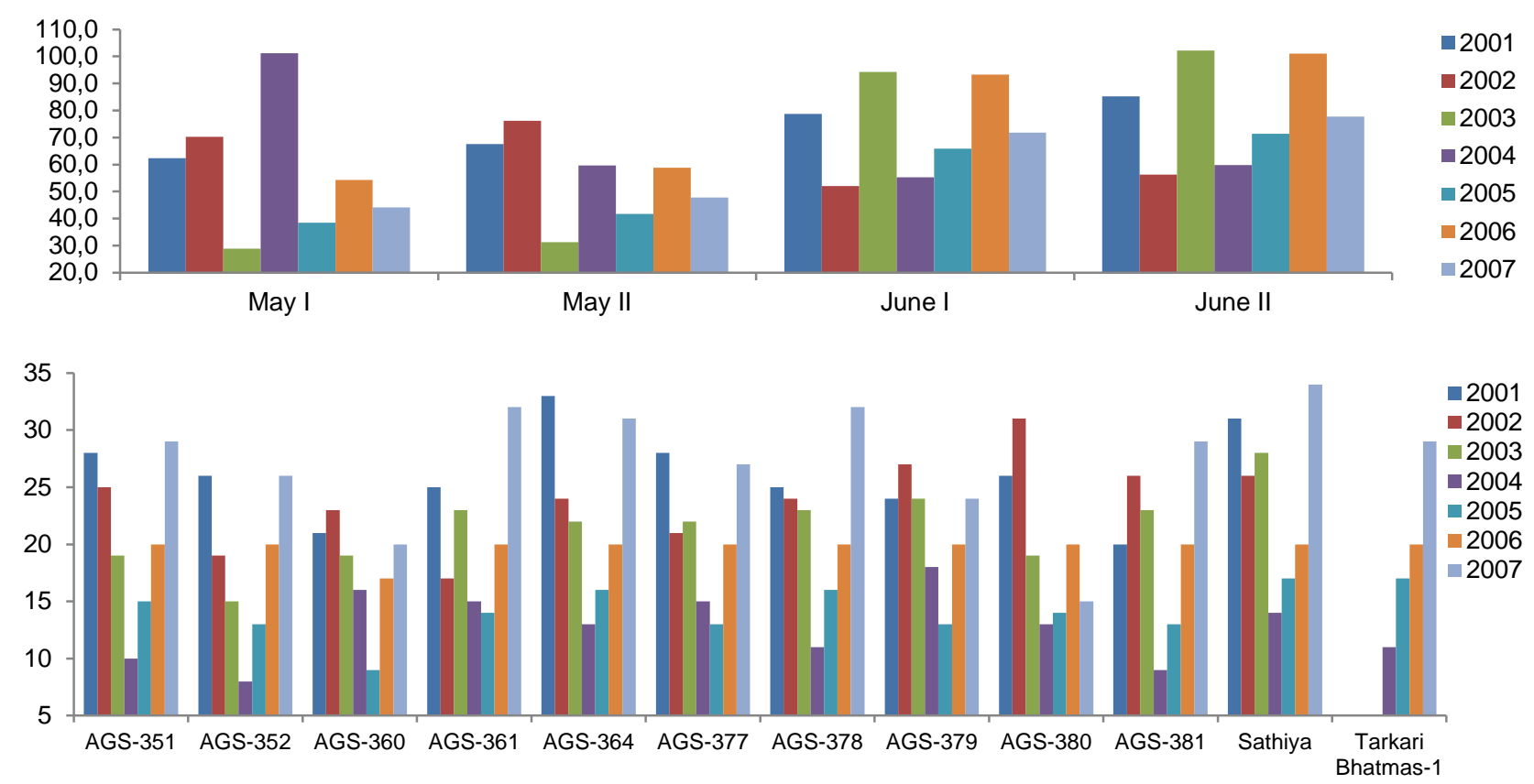

Figure 5 Soybean genotypes early stand (plant $/ \mathrm{m}^{2}$ ) and total rainfall from 2001 to 2007 . 


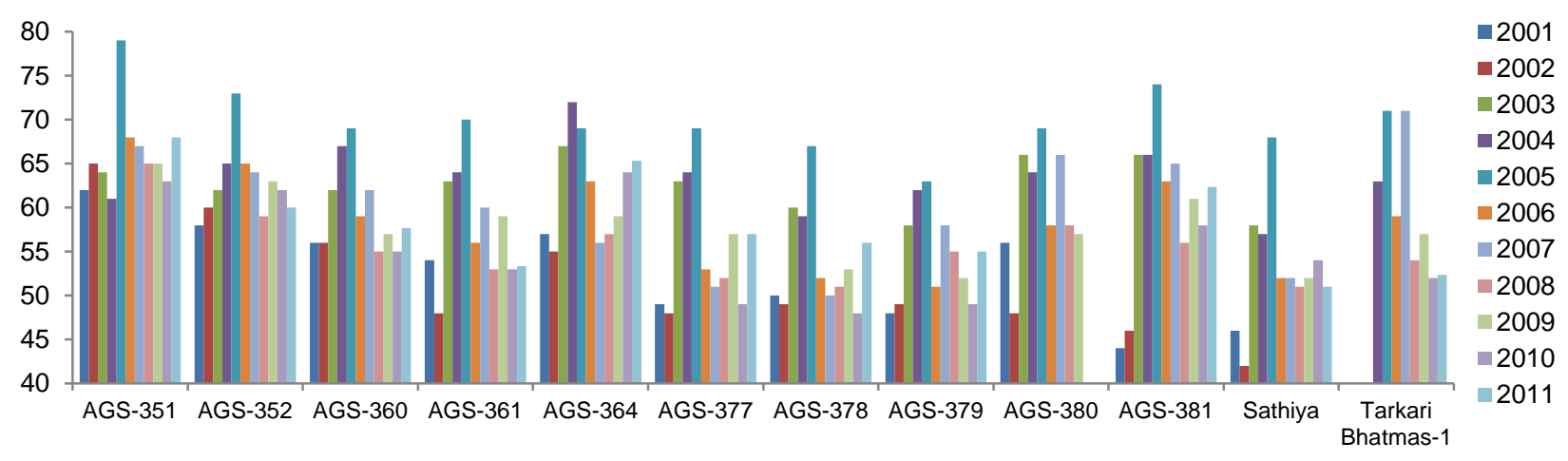

Figure 6 Soybean genotypes days from sowing to 50\% flowering from 2001 to 2011

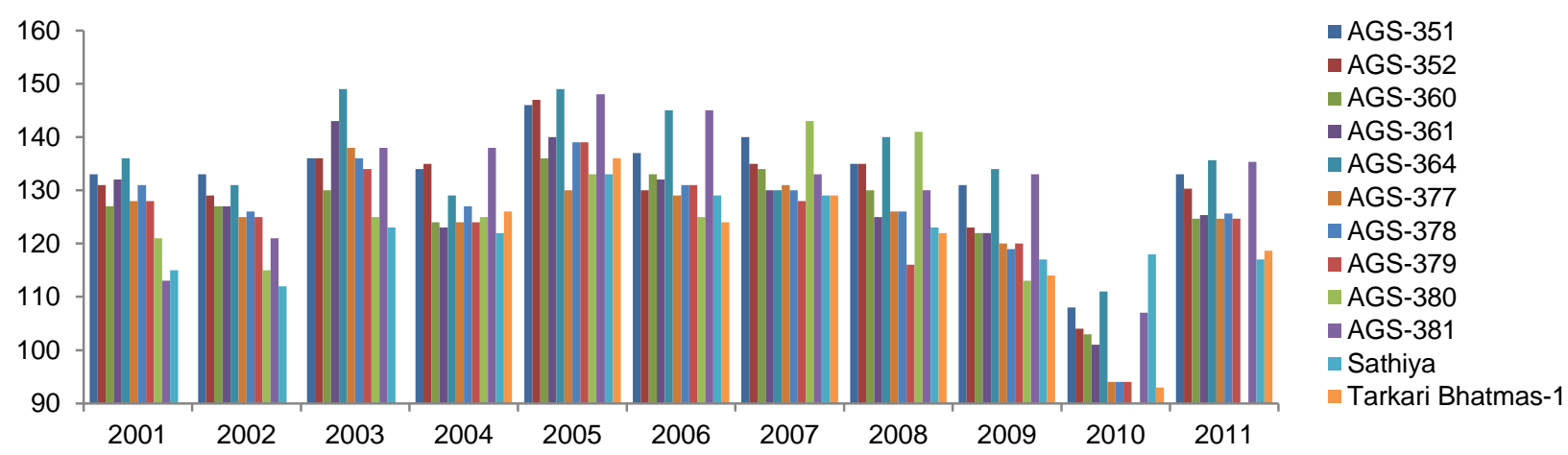

Figure 7 Soybean genotypes Days from Sowing to 90\% Maturity from 2001 to 2011

Table 1 Correlation of seed yield with climatic variation

\begin{tabular}{|c|c|c|c|c|c|c|c|c|c|c|c|c|c|}
\hline & $\begin{array}{l}\text { AGS- } \\
351\end{array}$ & $\begin{array}{l}\text { AGS- } \\
352\end{array}$ & $\begin{array}{l}\text { AGS } \\
-360\end{array}$ & $\begin{array}{l}\text { AGS- } \\
361\end{array}$ & $\begin{array}{l}\text { AGS- } \\
364\end{array}$ & $\begin{array}{l}\text { AGS- } \\
377\end{array}$ & $\begin{array}{l}\text { AGS- } \\
378\end{array}$ & $\begin{array}{l}\text { AGS- } \\
379\end{array}$ & $\begin{array}{l}\text { AGS- } \\
380\end{array}$ & $\begin{array}{l}\text { AGS } \\
-381\end{array}$ & Sathiya & $\begin{array}{l}\text { Tarkari } \\
\text { Bhatmas-1 }\end{array}$ \\
\hline \multirow{6}{*}{ 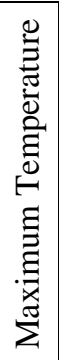 } & May & -.514 & -.253 & -.511 & -.355 & -.371 & -.411 & -.238 & -.123 & -.251 & -.157 & -0.238 & -.358 \\
\hline & \begin{tabular}{|l|} 
Jun \\
\end{tabular} & -.135 & .392 & .094 & .167 & -.047 & -.062 & .202 & .414 & .206 & .134 & 0.229 & .243 \\
\hline & \begin{tabular}{|l|} 
Jul \\
\end{tabular} & .48 & .504 & .164 & .46 & .499 & .466 & .474 & .368 & .443 & .461 & 0.265 & .489 \\
\hline & Aug & .581 & .56 & .344 & .587 & .569 & .477 & .543 & .419 & .538 & .502 & 0.442 & .593 \\
\hline & Sep & .199 & -.007 & .434 & .036 & .142 & .349 & .138 & .204 & -0.08 & 0.018 & 0.093 & -.006 \\
\hline & Oct & $.633^{*}$ & $.842 * *$ & .187 & $.85^{* *}$ & $.65^{*}$ & .527 & $.78 * *$ & $.667 *$ & $.89 * *$ & $.77 * *$ & $.724 *$ & $.817^{*}$ \\
\hline \multirow{6}{*}{ 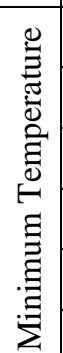 } & May & .047 & -0.167 & -.282 & $\begin{array}{l}.019 \\
\end{array}$ & -.008 & -.202 & $\begin{array}{l}.083 \\
\end{array}$ & -.331 & .073 & -0.06 & -0.086 & $\begin{array}{l}.058 \\
\end{array}$ \\
\hline & \begin{tabular}{|l|} 
Jun \\
\end{tabular} & .121 & -.115 & .17 & -.064 & -.095 & -.278 & -.179 & -.405 & .025 & -0.24 & 0.151 & -.052 \\
\hline & Jul & .462 & .494 & .493 & .568 & .46 & .244 & .513 & .427 & .588 & 0.422 & $.609 *$ & .501 \\
\hline & Aug & .394 & .239 & .19 & .269 & .392 & .398 & .398 & .238 & .326 & 0.325 & 0.265 & .306 \\
\hline & \begin{tabular}{|l|} 
Sep \\
\end{tabular} & -.313 & -.237 & -.188 & -.228 & -.27 & -.185 & .025 & $\begin{array}{l}.014 \\
\end{array}$ & -.011 & -0.16 & 0.002 & $-.766^{*}$ \\
\hline & Oct & .26 & $.757 * *$ & .106 & $.617 *$ & .287 & .231 & .59 & $.638^{*}$ & $.714 *$ & 0.536 & $.693 *$ & $.733^{*}$ \\
\hline \multirow{6}{*}{ 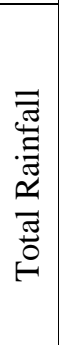 } & May & .036 & -.262 & .182 & -.017 & -.044 & -.084 & -.16 & -.192 & -.21 & -0.20 & \begin{tabular}{|l|}
-0.091 \\
\end{tabular} & -.202 \\
\hline & Jun & .076 & .165 & .266 & .227 & .216 & .218 & .365 & .317 & .5 & 0.226 & 0.285 & .113 \\
\hline & Jul & -.454 & $\begin{array}{l}-.008 \\
\end{array}$ & .09 & -.171 & -.514 & -.587 & -.425 & -.138 & -.32 & -0.42 & -0.037 & -.402 \\
\hline & Aug & .005 & .089 & .372 & .127 & .15 & .032 & .07 & .202 & -.025 & 0.053 & -0.012 & .013 \\
\hline & Sep & -.397 & -.169 & -.066 & -.15 & -.386 & -.318 & -.167 & -.06 & -.19 & -0.23 & 0.153 & -.208 \\
\hline & Oct & .448 & .578 & -.286 & .53 & .47 & .499 & .528 & .399 & .624 & $.637 *$ & 0.335 & .678 \\
\hline
\end{tabular}




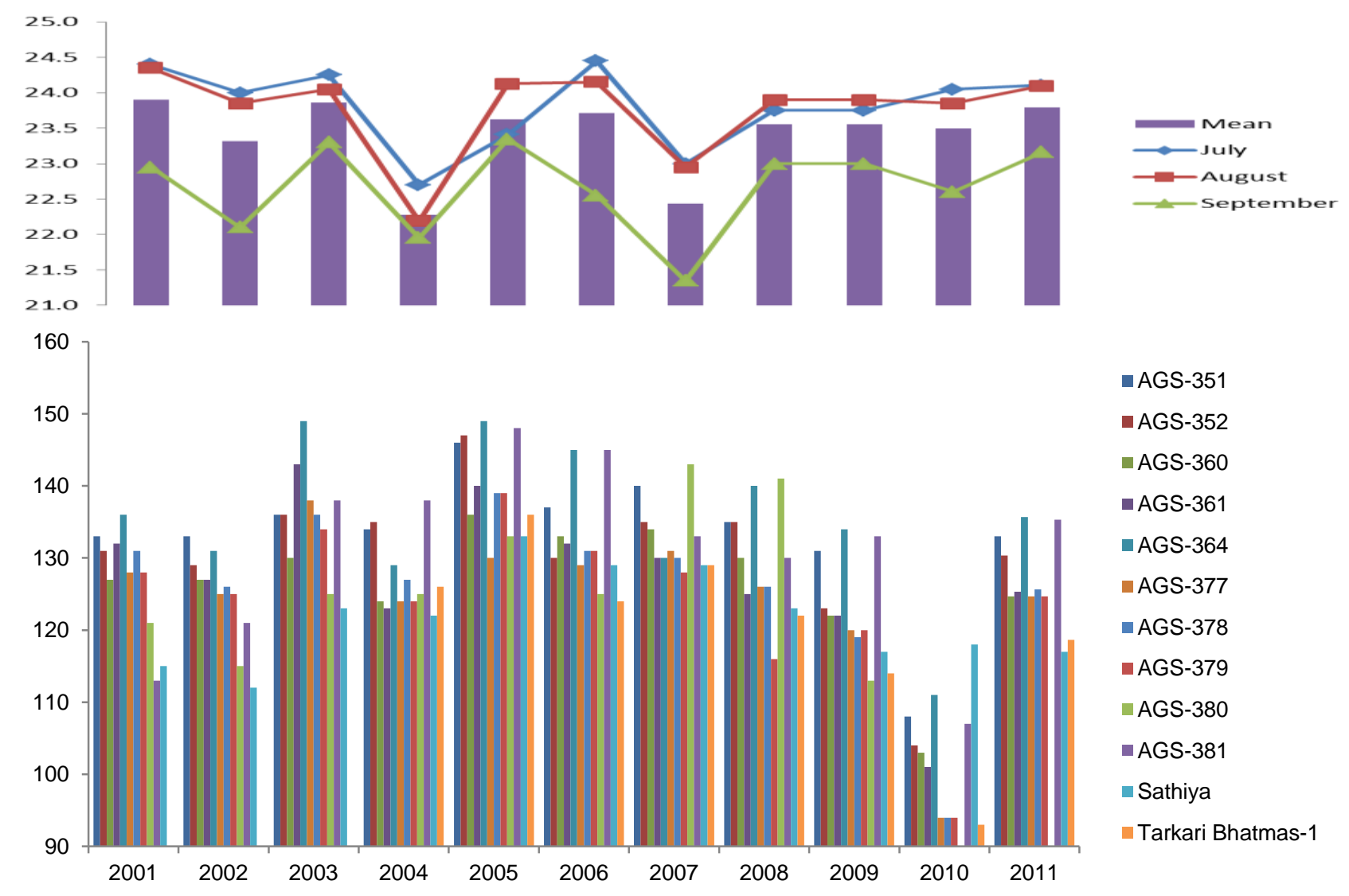

Figure 8 Soybean genotypes seed yield (kg/ha) and mean temperature $\left({ }^{\circ} \mathrm{C}\right)$ from 2001 to 2011.

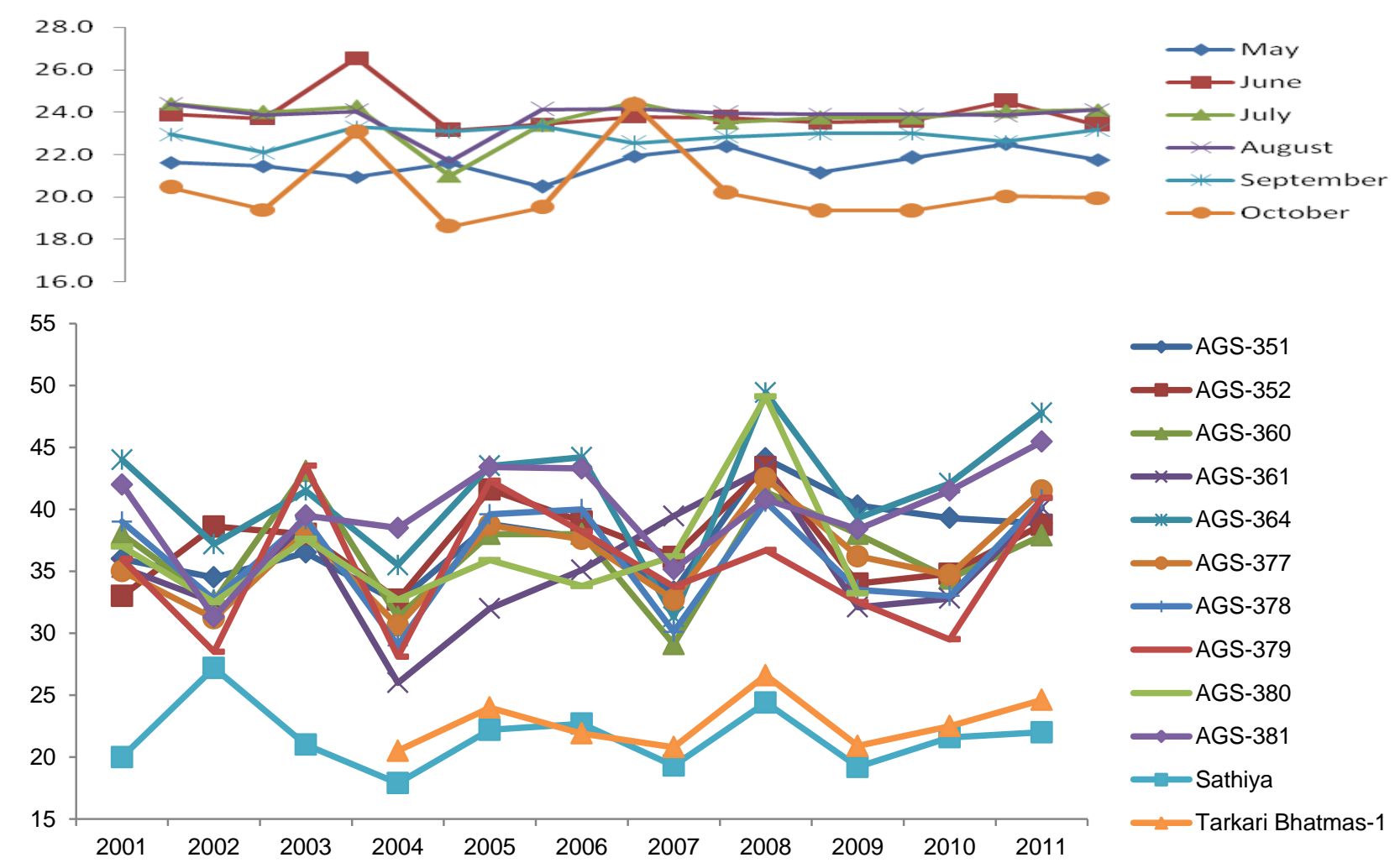

Figure 9 Soybean genotypes seed weight $(\mathrm{g})$ and mean temperature $\left({ }^{\circ} \mathrm{C}\right)$ from 2001 to 2011 


\section{Conclusion}

Mean maximum temperature in Khumaltar during soybean growing period was fluctuating but increasing trend. Minimum temperature at Khumaltar had decreasing trend at reproductive period and increasing in vegetative growth period. Likewise, amount of rainfall was not so decreased but rainy day was decreased during study period. Early plant stands high when rainfall high in Second week of May and first week of June i.e. sowing time. Days from sowing to $50 \%$ flowering and $90 \%$ maturity were short when minimum temperature high and low rainfall. Among the genotypes, AGS-377, AGS-378, AGS-379 and Tarkari Bhattmas-1 were more sensitive to the days from sowing to $50 \%$ flowering and $90 \%$ maturity. Seed yield also high in high minimum temperature and low rainfall during ripening stage. However, more rainfall occur during flowering stage and seed development stage and mean temperature was below $24^{\circ} \mathrm{C}$ during pod filling stage i.e. July to September, drastically reduced seed yield. In last three years, plant suffers from moisture stress during early vegetative stage and high moisture during late vegetative stage which reduced seed yield and seed weight. Genotypes like AGS360 , Sathiya and Tarkari Bhatmas-1 are very sensitive to climatic variation.

\section{References}

Bartlett R, Bharati L, Pant D, Hosterman H, McCornick P. 2010. Climate change impacts and adaptation in Nepal. Colombo, Sri Lanka: International Water Management Institute. 35p. (IWMI Working Paper 139).

Beggs PJ. 2004. Impacts of climate change on aeroallergens: past and future. Clin Exp Allergy, 34: 1507-1513.

Berglund DR. 2012. Assessing Frost Damage in Soybeans. Report presented in North Dakota State University, USA.

Boote KJ, Aleen LH, Prasad PVV, Baker JT, Gesch RW, Snyder AM, Pan D, Thomas JMG. 2005. Elevated temperature and carbon dioxide impacts on pollination, reproductive growth, and yield of several globally important Crops. J. Agric. Metero. Japan 60:469-474.
Dornbos Jr DL, Mullen RE. 1991. Influence of stress during soybean seed fill on seed weight, germination, and seedling growth rate. Journal of Plant Science, 71: 373-383.

Duthion C, Pigeaire A. 1991. Seed Lengths corresponding to the final stage in seed abortion of three grain Legumes. Crop Sci., 31: 1579-1583.

Jonathan MF, Nilton NC, Bruce B. 2004. Night temperature has a minimal effect on respiration and growth in rapidly growing plants. Annals of Botany 94: 155-166.

Krishnan V, Sachdev A. 2014. Agronomic Practices in soybean cultivation. http://www.krishisewa.com/cms/articles/productiontechnology/153-soybean production.html.

Liu X, Jian J, Guanghua W, Herbert SJ. 2008. Soybean yield physiology and development of high- yielding practices in Northeast China. Field Crops Research, 105: 157-171.

Mills D, Dorrance A. 2009. Mid-Season Soybean Disease-It's time to Scout. C.O.R.N. Newsletter 2009-23 (July 21, 2009 - July 28, 2009).

MOAD. 2014. Statistical information on Nepalese agriculture (2010/11). Ministry of Agriculture and Co-operatives, AgriBusiness Promotion and Statistics Division, Singha Durbar.

Nafziger E. 2012. Soybean. In Illinois Agronomy Handbook. University of Illinois, Champaign.

Prasad PVV, Craufurd PQ, Summerfield RJ. 2000. Effect of high air and soil temperature on dry matter production, pod yield and yield components of Groundnut. Plant and Soil, 222: 231-239.

Rahmani HA, Saleh rastin N, Khavazi K, Asgharzaden A, Fewer D, Kiani S, Lindstrom K. 2009. Selection of thermotolerant bradyrhizobial strains for nodulation of soybean (Glycine max L.) in semi-arid regions of Iran. World J. Microbiol. Biotechnol., 25: 600-591

Sharma KP. 1994. Soybean Production in Nepal: Past Achievements and Future Prospects. J. Inst. Agric. Anim. Sci. 15:19-26

Staton M. 2012. Moisture stress and high temperature effects on soybean yields. Michigan State University Extension.

Thuzar M, Puteh AB, Abdullah NAP, Lassim Mohd MB, Kamaruzaman J. 2010. The effects of temperature stress on the quality and yield of soybean [(Glycine max L.) Merrill.]. Journal of Agricultural Science 2: 172-179.

Zheng S, Nakamoto H, Yoshikawa K, Furuya T, Fukuyama M. 2002. Influences of high night temperature on flowering and pod setting in soybean. Plant Production Science 5: 215-218. 